\title{
Perceived Exertion and Energy Expenditure during Physical Activities in Healthy Young People and Older Adults
}

\author{
Oyéné Kossi ${ }^{1,2}$, Justine Lacroix ${ }^{1}$, Maxence Compagnat ${ }^{1,3}$, Jean Christophe Daviet ${ }^{1,3}$, \\ Stéphane Mandigout ${ }^{1}$ \\ ${ }^{1}$ HAVAE (Handicap, Aging, Autonomy, Environment) EA6310, Limoges University, Limoges, France \\ ${ }^{2}$ ENATSE - School of Public Health and Epidemiology, University of Parakou, Parakou, Benin \\ ${ }^{3}$ Department of Medicine and Physical Rehabilitation Service, Limoges University Hospital, Limoges, France
}

Corresponding author: Oyéné Kossi, Laboratoire HAVAE (EA 6310), 123 Avenue Albert Thomas, 87060 Limoges, France; E-mail: oyene.kossi@gmail. com; Tel.: +33 (0)555457632

Received: 18 July 2020 Accepted: 4 Nov 2020 Published: 31 Aug 2021

Citation: Kossi O, Lacroix J, Compagnat M, Daviet JC, Mandigout S. Perceived exertion and energy expenditure during physical activities in healthy young people and older adults. Folia Med (Plovdiv) 2021;63(4):502-10. doi: 10.3897/folmed.63.e56679.

\section{Abstract}

Aim: To test the validity of Borg's 6-20 rating of perceived exertion scale in assessing the exertion intensity over a multi-activity session in young and older adults.

Materials and methods: This cross-sectional study included 56 healthy participants. All participants underwent a single session of activities including working on a computer, treadmill walking, biking, and treadmill running.

Results: Results showed a non-significant correlation between the overall perceived exertion and energy expenditure in young people ( $R h o=-0.05, p=0.75)$ and in older adults $(R h o=-0.05, p=0.78)$ for the whole session. However, results showed that older adults perceived significantly higher exertion compared to young people while working on a computer, walking and running, whereas they presented lower energy expenditure while resting and working on a computer.

Conclusions: Combining the perceived exertion method with other commonly used methods to estimate exercise intensity would be recommended for older adults.

\section{Keywords}

Borg's scale, energy expenditure, older adults, physical activity, rating of perceived exertion

\section{INTRODUCTION}

Physical exercise has been identified as an effective and valuable lifestyle behaviour for preventing the multiple deleterious effects of aging and providing health benefits. ${ }^{1}$ As a consequence, there is a growing interest in promoting physical exercise prescriptions for the older adult population. Currently, there is scientific evidence that strongly supports the positive association between increased levels of physical activity and improved health in older adults. ${ }^{2}$ Optimizing their adherence to exercise programs, however, remains the major concern. ${ }^{3,4}$ Today, many recommendations are available to guide exercise prescription for health ${ }^{5}$ and disease prevention ${ }^{6}$. The most commonly used guideline refers to $30 \mathrm{~min}$ of moderate-intensity aerobic physical activity for 5 days a week or 20 min of vigorous-intensity aerobic physical activity for 3 days a week to promote or maintain health and cardio-respiratory fitness. ${ }^{5}$ This

Copyright by authors. This is an open access article distributed under the terms of the Creative Commons Attribution License (CC-BY 4.0), 
volume of physical activity has been equated to an approximate energy expenditure (EE) of 150 kilocalories per day $\left(\mathrm{kcal} \cdot \mathrm{d}^{-1}\right)$ or $1,000 \mathrm{kcal} \cdot \mathrm{wk}^{-1} \cdot{ }^{7}$ However, the recommendation for older adults has several important differences including the following: the recommended intensity of aerobic activity takes into account the older adult's aerobic fitness, activities that maintain or increase flexibility are recommended, and balance exercises are recommended for older adults to reduce the risk of falls. The promotion of physical activity in older adults should emphasize moderate-intensity aerobic activity, muscle-strengthening activity, and reducing sedentary behaviour. ${ }^{8}$

Currently, a number of potential indicators are used to increase our understanding of the exercise load and its effects on the individual, with the most commonly used ones being heart rate and ratings of perceived exertion (RPE). RPE is one of the most popular tools that are supposed to provide an understanding of physiological stress during exercise as well as retrospective information regarding perceived effort during exercise. ${ }^{9,10} \mathrm{RPE}$ is a psychophysiological marker of intensity reflecting a complex integration of subjective feelings of effort, strain, discomfort, and/or fatigue experienced during exercise. ${ }^{10,11}$

RPE scales, such as those developed by Borg (Borg $6-20)^{12}$, are tools that are often used to monitor and quantify individual's perceptions of effort during exercise. ${ }^{13}$ A vast amount of published research findings indicate strong concurrent validity for the Borg (6-20) Perceived Exertion Scale using physiological measures such as heart rate, blood lactate concentration, percent maximal oxygen uptake $\left(\% \mathrm{VO}_{2 \max }\right)$, oxygen uptake $\left(\mathrm{VO}_{2}\right)$, ventilation and respiration rate as criterion variables. ${ }^{12,14,15}$ However, little is known about the age dependent effect on exertional perceptions using a portable gas analyzer as a criterion measure.

\section{AIM}

This study therefore aimed to compare different levels of exercise intensity measured with the MetaMax3B in metabolic equivalent to the perceived exertion estimations using Borg's scale 6-20 over a multi-activity session in young people and older adults.

\section{MATERIALS AND METHODS}

\section{Participants and ethical considerations}

A convenience sampling approach was used to recruit participants (young people: aged 18-35 years and older adults: age $\geq 65$ years). Participants had to be in a healthy state with no need of assistive devices for mobility and no medical contraindication to the practice of PA. They refrained from eating, consuming caffeine, and smoking for at least two hours and refrained from exercise for 12 hours prior to the experimental session. The data collection took place at our laboratory's Department of Disability and Activity.

The local Ethics Committee for Non-Interventional Research approved the study protocol. Prior to the experiments, all participants signed an informed consent form after receiving oral and written descriptions of the research and the experimental procedures.

\section{Materials and procedures}

\section{Assessment of EE}

EE was measured by indirect calorimetry using a portable gas analyzer (MetaMax 3B Cortex; Cortex Medical, Leipzig, Germany). The MetaMax 3B is a portable metabolic measurement system comprising a measurement module and a battery module. It measures gas volume using a bidirectional digital turbine. The $\mathrm{O}_{2}$ and $\mathrm{CO}_{2}$ concentrations were measured using an electrochemical cell and an infrared analyzer. Respiratory "oxygen consumption $\left(\mathrm{VO}_{2}\right)$ " and "carbon dioxide production $\left(\mathrm{VCO}_{2}\right)$ " were calculated by standard metabolic algorithms based on the Haldane transformation. ${ }^{16}$ Respiratory volume data and respiratory gas concentrations were transmitted live by telemetry to a computer. The system was paired to the Metasoft 3 software, v3.7.0 SR2, for analysis. Breath-by-breath respiratory data were collected and averaged, with oxygen consumption $\left(\mathrm{L} \cdot \mathrm{min}^{-1}\right)$ converted to MET. Before each test, the MetaMax 3B was calibrated according to the manufacturer's guidelines. The average of the $3^{\text {rd }}$ and $4^{\text {th }}$ minute EE records was considered for the statistical analyses.

\section{RPE assessment}

The RPE was measured using the Borg 6-20 scale. ${ }^{12,13}$ The $\mathrm{RPE}$ is a 15-point item scale ranging from 6 to 20, with anchors ranging from 6 "no exertion" to 20 "maximum exertion". The RPE was assessed at the end of each exercise and also for the whole session with the following question: "What was the highest perceived intensity of effort during those tasks on a scale of 6 to 20, 6 being no effort and 20 being maximum intensity of effort". Before starting the experiment, participants were instructed on how to apply the RPE (6-20 Borg scale $)^{12}$ when requested by the experimenter. The range of sensations corresponding to the categories of effort within the scale was clearly explained to each participant.

\section{Physical activities}

The physical activities (PA) were designed based on the Compendium of Physical Activities ${ }^{17,18}$ and consisted in resting, working on a computer, treadmill walking at 4.6 $\mathrm{km} \cdot \mathrm{h}^{-1}$ (3.1 MET; moderate intensity), cycling (stationary cycle ergometry) at 70 watt (4.1 MET = moderate intensity), treadmill walking at $4.6 \mathrm{~km} \cdot \mathrm{h}^{-1}(3.3 \mathrm{MET}$; moderate intensity), and treadmill running at $5.8 \mathrm{~km} \cdot \mathrm{h}^{-1}$ for older 
adults and at $6.4 \mathrm{~km} \cdot \mathrm{h}^{-1}$ for young people (6.0 MET; high intensity). The session ended with a 5 -min recovery period. Older adults as well as young people were then required to complete the same 35 -min session of successive 5 -min exercises without rest. The exercises were not random; the participants were required to perform the activities in the same order.

\section{Statistical analysis}

Statistical analyses were performed using SigmaPlot software version 13.0. The Gaussian distribution of the variables was assessed using the Shapiro-Wilk test. Depending on the number of individuals in each subgroup, the chi-squared test and Fisher's exact test were used as appropriate to compare the distribution of qualitative variables, while the Mann-Whitney rank test or Student's t-test were used to compare the distribution of quantitative variables. Associations between EE and RPE were checked using the Spearman's correlation coefficient. The threshold of significance was set at 0.05 .

\section{RESULTS}

A total of 56 healthy participants were included in the study. The participants' characteristics are displayed in Table $\mathbf{1 .}$ The Shapiro-Wilk test indicated that the MetaMax3B data did not vary significantly from the pattern expected if data were drawn from a population with a normal distribution $(p>0.05)$. Consequently, parametric analyses were used where relevant in the data analysis.

Table 2 gives and compares data on the heart rate and oxygen consumption of the subjects during each physical activity. Results showed that older adults had significantly lower heart rates compared to young people while working on a computer and during recovery. Similarly, they presented lower oxygen consumption during resting and working on a computer.

Fig. 1 highlights the comparison of the RPE and the mean EE for the whole session in the two groups. It shows that there was no significant difference either in the perceived exertion as rated by young people compared to older adults or in the mean $\mathrm{EE}$ as given by the MetaMax $3 \mathrm{~B}$.

Table 1. Participants' characteristics

\begin{tabular}{llll}
\hline & $\begin{array}{l}\text { Young people } \\
(\mathbf{n = 2 9 )}\end{array}$ & $\begin{array}{l}\text { Elderly } \\
(\mathbf{n = 2 7})\end{array}$ & $\boldsymbol{p}$-value \\
\hline Sex (Male/Female) & $17 / 12$ & $7 / 20$ & $0.028^{*}$ \\
Smoke (Yes/No) & $2 / 27$ & $0 / 27$ & 0.49 \\
Age (years) & $24 \pm 4$ & $71 \pm 4$ & $<0.001^{*}$ \\
Height (cm) & $172 \pm 9$ & $163 \pm 8$ & $<0.001^{*}$ \\
Weight (kg) & $74 \pm 15$ & $68 \pm 14$ & 0.167 \\
Body Mass Index & $25 \pm 3$ & $25 \pm 4$ & 0.63 \\
\hline
\end{tabular}

Values reported as mean \pm SD for continuous variables and counts for categorical variables; ${ }^{*}$ : statistically significant

Table 2. Distribution and differences in heart rate and oxygen consumption between young people and older adults during each physical activity

\begin{tabular}{lllll}
\hline & Activities & Young people & Older adults & $p$-value \\
\hline & Resting & $80.09 \pm 24.45$ & $75.19 \pm 12.23$ & 0.23 \\
& Working on a computer & $82.98 \pm 21.89$ & $77.41 \pm 14.09$ & $0.049^{*}$ \\
Heart rate, Mean \pm SD & Cycling & $98.87 \pm 28.51$ & $98.03 \pm 23.01$ & 0.58 \\
& Walking & $99.42 \pm 32.73$ & $109.58 \pm 16.97$ & 0.39 \\
& Running & $132.90 \pm 34.75$ & $138.64 \pm 21.42$ & 0.69 \\
& Recovering & $107.11 \pm 27.13$ & $99.453 \pm 15.87$ & $0.06^{*}$ \\
Oxygen consumption, & Resting & $3.87 \pm 1.24$ & $3.30 \pm 1.15$ & $0.04^{*}$ \\
Mean \pm SD $\left(\mathrm{mL}^{-1} \cdot \mathrm{min}^{-1} \cdot \mathrm{kg}^{-1}\right)$ & Working on a computer & $4.68 \pm 1.47$ & $3.73 \pm 1.11$ & $<0.01^{\star}$ \\
& Cycling & $10.02 \pm 4.68$ & $8.86 \pm 2.96$ & 0.55 \\
& Rulking & $12.54 \pm 2.69$ & $13.85 \pm 3.23$ & 0.11 \\
& Recovering & $24.38 \pm 4.44$ & $23.05 \pm 3.00$ & 0.18 \\
\hline
\end{tabular}


Fig. 2 shows the correlation between the overall PE and $\mathrm{EE}$ in young people as well as in older adults for the whole session.

Table 3 gives the between-group (age) comparison of the RPE and the mean EE for each single task. Results showed that older adults perceived significantly higher exertion compared to young people while working on a computer, walking and running, whereas they presented lower EE during resting and working on a computer. Indeed, the exertion was perceived respectively as "extremely light", "fairly light" and "somewhat hard" by older adults, while it was perceived respectively as "no exertion", "very light" and "fairly light" by young people.

Fig. 3 depicts the correlation between the RPE and EE in the two groups for each single task. Overall, there was no significant correlation between the two measurements in older adults, whereas significant correlations were found in young people while cycling and during the recovery period.

\section{DISCUSSION}

To the best of our knowledge, this study is one the few that has evaluated and compared the RPE for the assessment of exercise intensity over a multi-activity session among young people and older adults. The primary finding of the present work is the inconsistency in the perceived exertion in young people and older adults upon execution of the exercises.

Although the participants were submitted to the same intensity of physical activity in this study, we found differences in the RPE in older adults compared with young
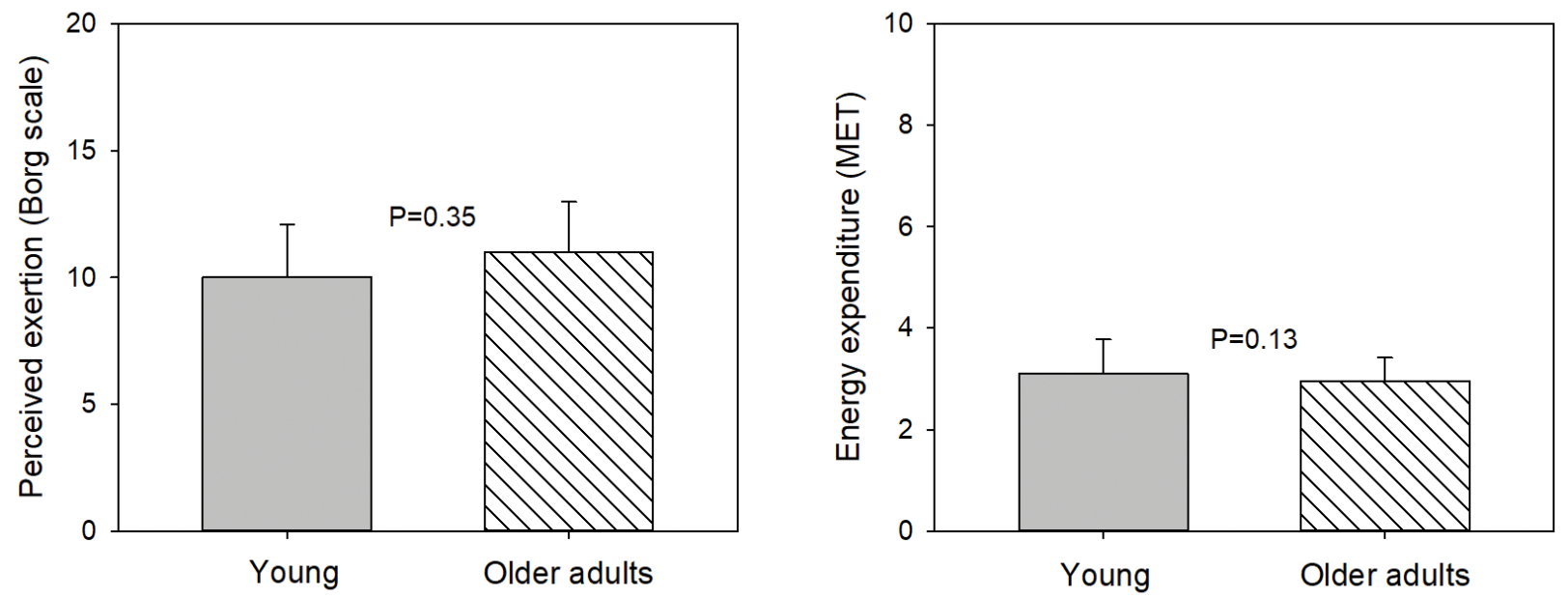

Figure 1. Perceived Exertion (PE) and Energy Expenditure (EE) estimates in young people and older adults. The left panel gives the PE estimations with the Borg's scale while the right panel gives the EE estimation with the MetaMax $3 \mathrm{~B}$.
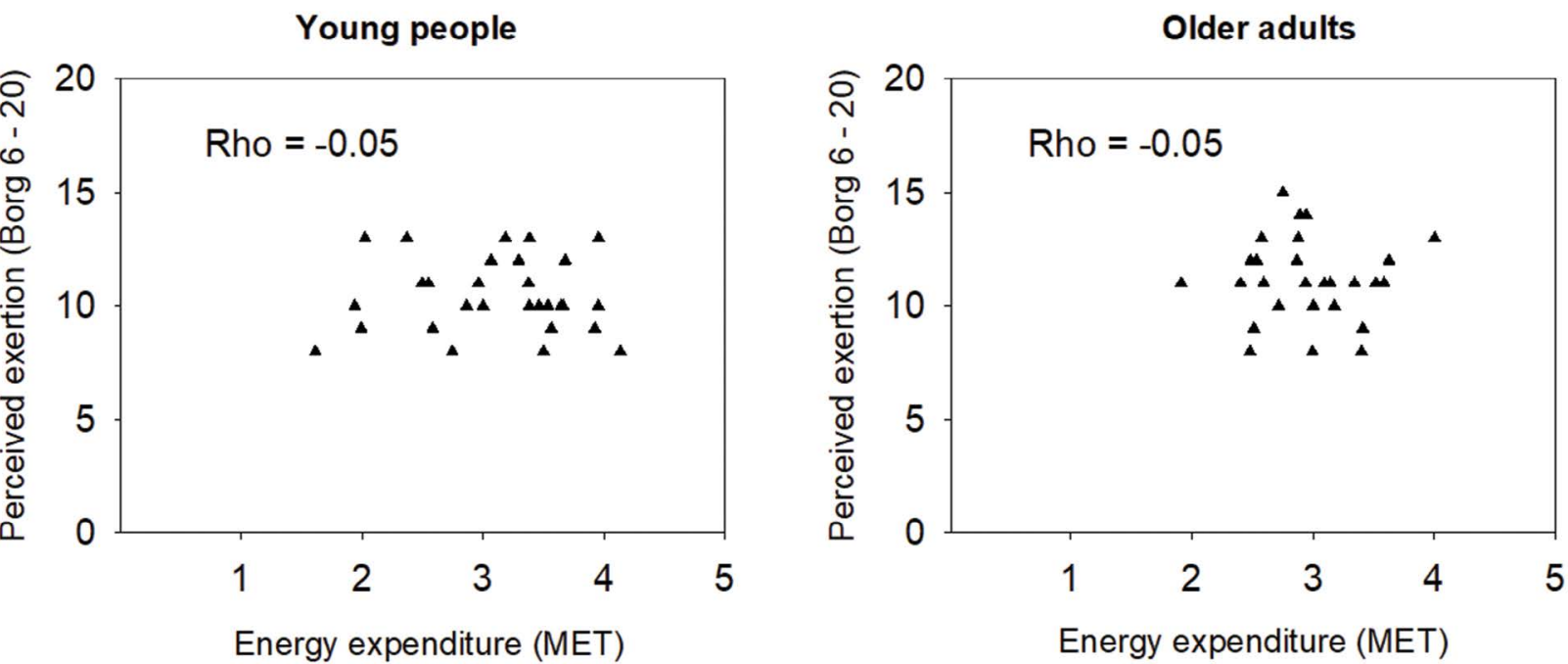

Figure 2. Relationships between EE and PE for the whole session in young people and older adults. The left panel depicts the relationship between $\mathrm{EE}$ and PE estimates in young people while the right panel depicts the relationship between EE and PE estimates in older adults. 
Table 3. Comparison of energy expenditure and perceived exertion between young people and older adults

\begin{tabular}{lllll}
\hline & Activities & Young people & Older adults & $p$-value \\
\hline & Resting & $6[6,6]$ & $6[6,6]$ & 0.53 \\
Perceived exertion, & Working on a computer & $6[6,7]$ & $7[6,8]$ & $0.02^{*}$ \\
Median [P25, P75] & Cycling & $8[7,9]$ & $8[7,10]$ & 0.24 \\
& Walking & $8[8,9]$ & $10[8,12]$ & $<0.01^{*}$ \\
& Running & $11[10,12]$ & $13[12,15]$ & $<0.001^{*}$ \\
& Recovering & $7[7,8]$ & $8[7,10]$ & 0.09 \\
\hline Energy expenditure, & Resting & $1.11 \pm 0.35$ & $0.94 \pm 0.32$ & $0.04^{\star}$ \\
Mean \pm SD (MET) & Working on a computer & $1.33 \pm 0.42$ & $1.07 \pm 0.31$ & $0.01^{*}$ \\
& Cycling & $2.86 \pm 1.34$ & $2.53 \pm 0.84$ & 0.55 \\
& Walking & $3.58 \pm 0.76$ & $3.96 \pm 0.92$ & 0.10 \\
\hline
\end{tabular}

*: statistically significant; P: percentile; MET: metabolic equivalent

people. Indeed, older adults perceived significantly higher exertion compared to young people while working on a computer, walking and running. These findings are in line with those of Jabbour and Majed ${ }^{10}$ who found that older adults perceived a significantly higher effort at the same relative submaximal intensities compared to young people. In their study, the participants performed a maximal incremental exercise test on a cycle ergometer. The test began at an initial power of 25 watts and increments of 25 watts followed every $5 \mathrm{~min}$ until exhaustion. During the test, the participants were instructed to pedal at a rate of 50 70 revolutions per minute. The test was terminated when the participants requested to stop the exercise or could no longer maintain the required pedalling rate. ${ }^{10}$ Their results showed that at a relative intensity $\left(49 \%-51 \% \mathrm{VO}_{2}\right.$ peak $)$ older adults judged the effort as being "very hard" compared to a "fairly light" rating for the young group. This was also the case at $80 \% \mathrm{VO}_{2}$ peak, where the older group judged the effort as being "very, very hard" compared to "somewhat hard to hard" for the young group. ${ }^{10}$ The discrepancy observed in RPE between the two groups may be explained by age, which has the potential to influence RPE as previously reported. Actually, some authors have reported that, with aging, many factors impair the cognitive functions among elders leading to an alteration of their perceived exertion. ${ }^{19}$ A previous study has also suggested that aging and physical deconditioning may decrease the sensitivity of proprioceptors in older adults by decreasing the speed and the quality of nervous transmission. ${ }^{20}$ Accordingly, Grange et al. ${ }^{21}$ did not find any association between RPE and other physiological indicators (e.g., heart rate) during the course of a graded arm test to maximal exertion among inexperienced older groups. On the contrary, Sidney and Shephard ${ }^{14}$ and Aminoff et al. ${ }^{22}$ reported that RPE is not impaired by aging and can be used as a tool to control exercise intensity in healthy middle-aged and older individuals. For these authors, perceived exertion is affected more by the physical fitness and the health status of the subject than by aging alone.

A common classification of physical activity intensity uses MET values as follows: $<3$ METs = light, 3-6 METs $=$ moderate, $>6$ METs $=$ vigorous. ${ }^{5}$ Currently, widely endorsed recommendations state that adults should strive to accumulate at least 30 minutes of moderate-intensity physical activity on most days of the week. ${ }^{23}$ In the present study, two activities, for either age group, elicited mean intensities within the moderate or high range of 3-6 or $>6$ METs. Exertion was perceived, however, respectively as "fairly light" and "somewhat hard" by older adults while it was perceived respectively as "very light" and "fairly light" by young people. Thus, although the participants were submitted to the same absolute exercise intensity, the RPE was higher in older adults compared to young people. These observations are consistent with those of Bar-Or et al. ${ }^{24}$ who reported that in young people and older adults, when comparisons are made at the absolute exercise intensity (i.e. the same work rate or power output), RPE is generally lower in young people than in middle-aged persons. In fact, some authors have reported that cerebral flow diminishes with aging which may lead to a decrease in cognitive functions that may affect perceived exertion in older persons. ${ }^{25}$ In light of some reports of inverse relationships between physical activity intensity and RPE, ${ }^{3,4}$ a greater sense of effort could have implications for continued participation. While older adults rated the activities as more difficult than young people, their overall RPE still corresponded to "light" or "somewhat hard" on Borg's scale.

Perceived exertion is a psychophysiological marker of intensity resulting from the complex integration of subjective feelings of effort, strain, discomfort, and/or fatigue experienced during exercise. ${ }^{11}$ Among RPE scales, the Borg's scale is one of the most popular and is used to provide an understanding of the physiological stress during exercise as well as retrospective information regarding perceived effort during exercise. ${ }^{9}$ The findings of the present study showed that there was no significant correlation 


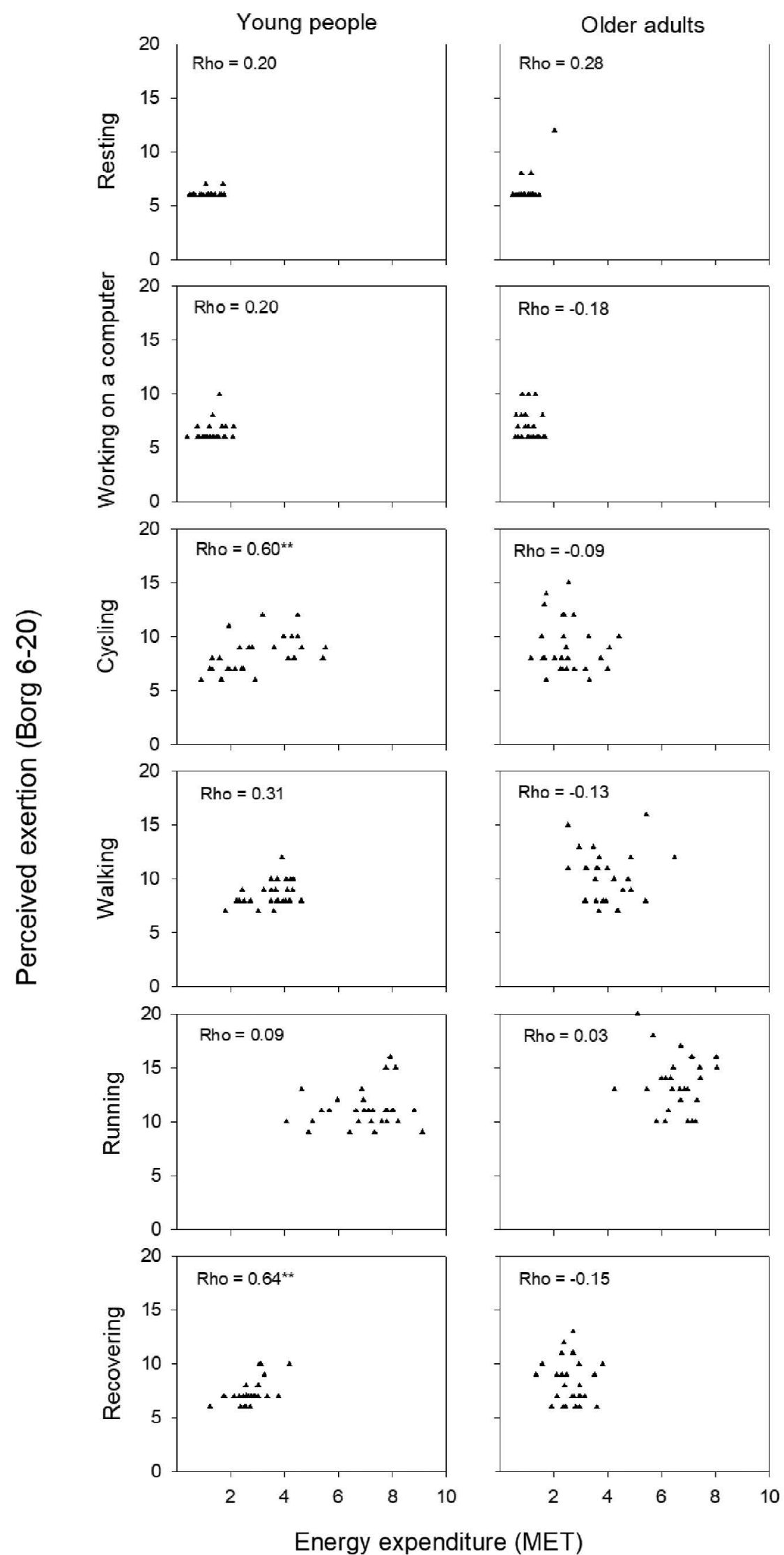

Figure 3. Relationships between EE and PE in young people and older adults according to the physical activity. The right column shows the relationships in young people while the left column shows the relationships in older adults. 
between EE and RPE in older adults not only in each single exercise, but also for the whole session. Previous studies have reported that errors of production estimation from cycling or treadmill estimations in older adults reach approximately $50-70 \%$ of heart rate reserve. Nevertheless, several studies have demonstrated that Borg's RPE is an affordable, practical, and valid tool for monitoring and prescribing exercise intensity, independent of gender, age, exercise modality, and physical activity level. Indeed, in an experimental study aiming to examine the validity and reliability of Borg's 6-20 Rating of Perceived Exertion (RPE) scale in monitoring exercise intensity, Chung et al. ${ }^{26}$ found that the scale could be used as a valid and reliable tool for monitoring exercise intensity among the Chinese older adults. Recently, de Souza et al. ${ }^{27}$ examined the validity, reliability, and diagnostic accuracy of rating of perceived exertion (RPE) to identify dependence in performing selfcare activities in older women. The authors concluded that it was possible to use the perceived exertion to identify dependence in performing activities of daily living in older women. In a review aiming to summarize data pertaining to the rating of perceived exertion (RPE) methods during combat sport-specific activities based on many factors, including age of participants, Slimani et $\mathrm{al}^{28}$ found that rating of perceived exertion is a valid tool for quantifying internal training and combat loads during short- and longterm training and simulated and official competitions in novice and elite combat sport athletes. ${ }^{21}$ They concluded that coaches, sports scientists, and athletes can use sessionRPE method to quantify short-term training and combat loads in adult athletes during precompetitive period much more than long-term training and in young athletes during the competitive period.

\section{Implications and clinical impact}

Clinicians and researchers in the physical activity domains usually use ratings of perceived exertion in clinical and research settings for estimating intensity of exertion. They should be aware of the potential limitations of these subjective scales, notably in older adults. Our findings suggest that for older adults, practitioners and/or researchers should, insofar as possible, combine objective measurements of EE and subjective estimations of the associated perceived intensity of exertion.

\section{Study limitations}

There are some potential limitations in the current study that should be considered. First, the fact that it took place in a laboratory context may limit the generalization of our findings. Indeed, although the physical activities performed here are common in the targeted populations, assessing the physical activities of older adults in real-life and home-based situations is essential to be able to provide personalized programs aiming toward the maximization of long-term adherence to physical activity. Secondly, with the aging of the population, one could expect to have data that are more heterogeneous with these types of experimentations involving older adults.

\section{CONCLUSIONS}

This work provides some insight into the validity of the Borg's 6-20 scale in the estimation of the perceived exertion during a set of common physical activities in young people and older adults. Our findings complement those of earlier studies, showing that RPE would appear to be useful to prescribe and self-regulate exercise intensity in young people whereby targeting exercise intensity using fixed energy expenditure cannot be generated across both younger and older age groups. Therefore, combining the RPE method with other commonly used methods (e.g., heart rate) of estimating exercise intensity is recommended for older adults to suitably monitor their exercise intensity. Furthermore, in the light of our results, we can suggest that future studies should be devoted to adapting the Borg's 6-20 scale to older adults.

\section{Acknowledgments}

We thank all the participants for their helpful involvement in this study. We are also grateful to the Partnership Foundation at Limoges University (France) for its financial support.

\section{Funding}

This work was supported in part by the Partnership Foundation at Limoges University, France.

\section{Conflict of Interest}

The authors declare no conflict of interest.

\section{REFERENCES}

1. Hale D, Marshall K. Physical activity for older adults. Home Healthc Now 2017; 35(3):172-3.

2. Taylor D. Physical activity is medicine for older adults. Postgrad Med J 2014; 90(1059):26-32.

3. Perri MG, Anton SD, Durning PE, et al. Adherence to exercise prescriptions: effects of prescribing moderate versus higher levels of intensity and frequency. Health Psychol 2002; 21(5):452-8.

4. Lee JY, Jensen BE, Oberman A, et al. Adherence in the training levels comparison trial. Med Sci Sports Exerc 1996; 28(1):47-52.

5. Haskell WL, Lee I-M, Pate RR, et al. Physical activity and public health: updated recommendation for adults from the American College of Sports Medicine and the American Heart Association. Med Sci 
Sports Exerc 2007; 39(8):1423-34.

6. Billinger SA, Arena R, Bernhardt J, et al. Physical activity and exercise recommendations for stroke survivors: a statement for healthcare professionals from the American Heart Association/American Stroke Association. Stroke 2014; 45(8):2532-53.

7. Thompson PD, Arena R, Riebe D, et al. ACSM's new preparticipation health screening recommendations from ACSM's guidelines for exercise testing and prescription, ninth edition. Curr Sports Med Rep 2013; 12(4):215-7.

8. Nelson ME, Rejeski WJ, Blair SN, et al. Physical activity and public health in older adults: recommendation from the American College of Sports Medicine and the American Heart Association. Circulation 2007; 116(9):1094-105.

9. Halson SL. Monitoring training load to understand fatigue in athletes. Sports Med 2014; 44 Suppl 2:S139-47.

10. Jabbour G, Majed L. Ratings of perceived exertion misclassify intensities for sedentary older adults during graded cycling test: effect of supramaximal high-intensity interval training. Front Physiol 2018; 9:1505.

11. Robertson RJ, Noble BJ. Perception of physical exertion: methods, mediators, and applications. Exerc Sport Sci Rev 1997; 25:407-52.

12. Borg G. Perceived exertion as an indicator of somatic stress. Scand J Rehabil Med 1970; 2(2):92-8.

13. Borg GA. Psychophysical bases of perceived exertion. Med Sci Sports Exerc 1982; 14(5):377-81.

14. Sidney KH, Shephard RJ. Perception of exertion in the elderly, effects of aging, mode of exercise and physical training. Percept Mot Skills 1977; 44(3 Pt 1):999-1010.

15. Chen MJ, Fan X, Moe ST. Criterion-related validity of the Borg ratings of perceived exertion scale in healthy individuals: a meta-analysis. J Sports Sci 2002; 20(11):873-99.

16. Haugen HA, Chan L-N, Li F. Indirect calorimetry: a practical guide for clinicians. Nutr Clin Pract 2007; 22(4):377-88.

17. Ainsworth BE, Haskell WL, Whitt MC, et al. Compendium of physical activities: an update of activity codes and MET intensities. Med Sci Sports Exerc 2000; 32(9 Suppl):S498-504.
18. Ainsworth BE, Haskell WL, Leon AS, et al. Compendium of physical activities: classification of energy costs of human physical activities. Med Sci Sports Exerc 1993; 25(1):71-80.

19. Chodzko-Zajko WJ, Moore KA. Physical fitness and cognitive functioning in aging. Exerc Sport Sci Rev 1994; 22:195-220.

20. LaFratta CW, Canestrari R. A comparison of sensory and motor nerve conduction velocities as related to age. Arch Phys Med Rehabil 1966; 47(5):286-90.

21. Grange CC, Maire J, Groslambert A, et al. Perceived exertion and rehabilitation with arm crank in elderly patients after total hip arthroplasty: a preliminary study. J Rehabil Res Dev 2004; 41(4):611-20.

22. Aminoff T, Smolander J, Korhonen O, et al. Physical work capacity in dynamic exercise with differing muscle masses in healthy young and older men. Eur J Appl Physiol Occup Physiol 1996; 73(1-2):180-5.

23. Nelson ME, Rejeski WJ, Blair SN, et al. Physical activity and public health in older adults: Recommendation from the American College of Sports Medicine and the American Heart Association. Med Sci Sports Exer 2007; 39(8):1435-45.

24. Bar-Or O, Skinner J, Buskirk E, et al. Physiological and perceptual indicators of physical stress in 41-to-60-year-old men who vary in conditioning level and in body fatness. Med Sci Sports 1972; 4(2):96-100.

25. Chodzko-Zajko WJ, Moore KA. Physical fitness and cognitive functioning in aging. Exerc Sport Sci Rev 1994; 22:195-220.

26. Chung P-K, Zhao Y, Liu J-D, et al. A brief note on the validity and reliability of the rating of perceived exertion scale in monitoring exercise intensity among Chinese older adults in Hong Kong. Percept Mot Skills 2015; 121(3):805-9.

27. de Souza DM, Lopes PB, Marcora SM, et al. Validity, reliability, and diagnostic accuracy of ratings of perceived exertion to identify dependence in performing self-care activities in older women. Exp Aging Res 2018; 44(5):397-410.

28. Slimani M, Davis P, Franchini E, et al. Rating of perceived exertion for quantification of training and combat loads during combat sport-specific activities: a short review. J Strength Cond Res 2017; 31(10):2889-902. 
O. Kossi et al

\title{
Воспринимаемая фризическая нагрузка и расход энергии во время фризической активности у здоровых молодых людей и пожилых людей
}

\author{
Ойен Коси ${ }^{1,2}$ Жустин Лакроа ${ }^{1}$, Максенс Компаня ${ }^{1,3}$, Жан Кристоф Давие ${ }^{1,3}$, \\ Стефан Мандигу ${ }^{1}$ \\ 1 Лаборатория HAVAE (Handicap, Aging, Autonomy, Environment) ЕА6310, Лиможский университет, Лимож, Франици \\ ${ }^{2}$ ENATSE - Факультет общественного здравоохранения и эпидемиологии, Университет Параку, Параку, Бенин \\ ${ }^{3}$ Департамент медицины и физической реабилитации, Университетская больница Лиможа, Лимож, Франиия
}

Адрес для корреспонденции: Ойен Коси, Лаборатория HAVAE (ЕА 6310), 123 Авеню „Албер Томас“ №123, 87060 Лимож, Франция; E-mail: oyene.kossi@gmail.com; Тел.: +33 (0)555457632

Дата получения: 18 июля 2020 Дата приемки: 4 ноября $2020 \bullet$ Дата публикации: 31 августа 2021

Образец цитирования: Kossi O, Lacroix J, Compagnat M, Daviet JC, Mandigout S. Perceived exertion and energy expenditure during physical activities in healthy young people and older adults. Folia Med (Plovdiv) 2021;63(4):502-10. doi: 10.3897/folmed.63.e56679.

\section{Резюме}

Цель: Проверить валидность шкалы оценки воспринимаемой нагрузки Борга 6-20 при оценке интенсивности сеанса с несколькими видами деятельности для молодых людей и для пожилых людей.

Материалы и методы: В настоящее исследование включены 56 здоровых участников. Все участники прошли один сеанс деятельности, включая работу на компьютере, ходьбу по беговой дорожке, езду на велосипеде и бег по беговой дорожке.

Результаты: Результаты показали незначительную корреляцию между общей воспринимаемой нагрузкой и расходом энергии у молодых людей $(R h o=-0.05, p=0.75)$ и у пожилых людей $(R h o=-0.05, p=0.78)$ в течение всего сеанса. Однако результаты показали, что пожилые люди воспринимают значительно более высокую физическую активность по сравнению с молодыми людьми при работе с компьютером, ходьбе и беге, но имеют более низкий расход энергии во время отдыха и работы за компьютером.

Заключение: Пожилым людям рекомендуется комбинировать метод воспринимаемой нагрузки с другими широко используемыми методами оценки интенсивности упражнений.

\section{Ключевые слова}

шкала Борга, расход энергии, пожилые люди, физическая активность, оценка воспринимаемой нагрузки 